\title{
薄板の一体成形による平行平板構造を用いた 吊り下げ型角速度センサ
}

\begin{tabular}{|c|c|c|c|c|c|}
\hline 学生員 & 佐 藤 & 宏 & 司 & s & 名古屋大学 \\
\hline E 員 & 新 & 题 & 人 & 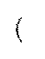 & 名古屋大学 \\
\hline 員 & 福 田 & 敏 & 男 & . & 名古屋大学 \\
\hline & 糸魚 & & 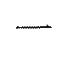 & & 会社 東海理 \\
\hline & $t=$ & & & & 会社 東海 \\
\hline
\end{tabular}

Dangler Type Vibrating Gyroscope Using the Parallel Beam Structure by the Sheet Metal Molding

Hiroshi SATO, Student Member, Fumihito ARAI, Member, Toshio FUKUDA, Member (Nagoya University), Kouichi ITOIGAWA, Member, Yasunori Tsukahara, Non-member (Tokai Rika Co., LTD.)

We produced a new vibrating gyroscope using a parallel beam structure. This gyroscope has some following sigunificant features, (1) The sensor device does not interfere to the reference vibration of the drive device. (2) This structure can convert the small Coriolis force into large concentrate strain. (3) Resonance frequency of the drive unit and the sensor unit can be easily adjusted by changing the mass of the tip. (4) Mechanical coupling can be suppressed by applied voltage to sensor device. However, this gyroscope is unsuitable for the mass-production, since the structure is complicated.

In this paper, we solve this problem by the presswork and the hydrothermal method. We optimized of the parallel beam gyroscope for the presswork based on the FEM analysis, and put PZT thin films by the hdyrothermal method. Using these two methods, we produced the dangler type gyroscope suitable for the mass production of a small size gyroscope with the advantage of the parallel bean structure.

キーワード：唗動型ジャイロヒンサ、平行平板構造、プレス加工、水熱合成法、PZT 薄膜

Keywords : Vibrating Gyroscope, Parallel Beam Structure, Press Work, Hydrothermal Method, PZT Thin Film

\section{1. はじめに}

近年、圧電材料を利用した振動型ジャイロセンサ（봅 叉型、音片型、三角柱型等) が小型、低価格でビデオカ メラの手振れ補正、車の姿勢制卸やナビゲーションシス テム等に広く利用きれている(1)(2)(3)(4)(5)。

正電材料を用いた振動型ジヤイロセンサは、一般に歌 動用と檢出用の2 種類の圧電材料を用いる。まず駆動用 の压電材料に電任文加之逆玨電効果を用いて参照振動を 励振する。その後回転が加わった時に参照振動に詨して 直交する方向に発生するコリオリ力を、検出用の圧電材 料に生じる歪みから正圧電効果により電気信号に変換し 検出している (2) (3) (5)。検出原理が単純であり、機械的な 磨耗部分がないためメンテナンスフリーであることから、 コマ型ジャイロ、リングレーザージャイロや光ファイバー
ジャイロ等の従来からあるジャイロセンサと比べ小型で 低価格である特徴を持っている:しかしコリオリ力によ り生じる歪みは微弱なため、高感度な振動型ジャイロ七 ンサを作製することは困難である。

我々は加点た力を集中嫼みに変換するすることのでき る平行平板構造を利用し、(1) 検出部と駆動部が干涉を起 こしにくく(2) コリオリカによる変形を集中歪みに変換 し(3) 共振周波数の調整が簡単に行うことができ (4) 漏 れ振動の抑制が可能な特長を持つ振動型ジャイロセン山 の䂨筧を行ってきた〈(日)(7)

しかし我々の提案した平行平板型ジかイロセンサは構 造が複雑で機械切削時の加工精度、压電材の镸り合わせ 誤差などによる漏れ振動の增大、及び作製コストの面で 問題があった。本論文ではこの問題に対して、機械切削 による平行平板構造の作慗の代りにプレス加工による構 
造の作製、上部の構造竞部の中に折り込むことによる 構造の小型化及びモーメントの影響の軽減、4 枚の圧電 材の張り合わせの代りに水熱合成法による圧電材料の一 括製膜を行い、切削加工による加工誤差や圧電材の張り 合わせ位置のずれの影響を軽減し、量産性に適した振動 型ジャイロセンサの作製、評価を行った。

\section{2. 平行平板型ジャイロセンサ}

我々の提案した平行平板型ジャイロセンサは平行平板構 造の以下のような特徴を利用することにより、高感度化 を行っている。(1) 可動端は駆動方向に平行に移動する。 （2）駆動方向に加わる力を集中歪みに変換する。(3) 駆動 方向以外には剛性が高く、歪みの集中は起こらない (9)。 この構造は畑村らによりこれまでに歪みゲージ等を利用 しピン型ロードセルや多軸のカセンサ等に用いられてき た (10)(11)。

平行平板型ジャイロセンサの構造は図 1(a) に示すよう に大きさは縦 $5 \mathrm{~mm}$ 、横 $5 \mathrm{~mm}$ 、高さ $24 \mathrm{~mm}$ の直方体の金 属 (SUS304) に切削加工により平板部の厚みが $250 \mu \mathrm{m} に$ なるように貫通する穴（上部：幅 $4.5 \mathrm{~mm}$ 、高さ $10 \mathrm{~mm}$ 、 下部：幅 $4.5 \mathrm{~mm}$ 、高さ $8 \mathrm{~mm}$ ) を空け、上下 2 つの平行平 板構造を作製している。上部と下部の平行平板構造の駆 動方向は直交しているため、外部から力が加わってもそ れぞれの駆動方向にのみ変形がおこり、干渉はおこらな い。また外部から加わった力は平行平板構造の平板部と 結合部の境界で集中歪みに変換される。

この構造の 4 つの側面に上下 2 分割した圧電材料 (PZT 板、長さ $12 \mathrm{~mm}$ 、幅 $5 \mathrm{~mm}$, 厚み $150 \mu \mathrm{m})$ を貼付け振動型 のジャイロセンサを作製している。下部の圧電材料に位 相の 180 度異なる駆動電圧を上下の電極に加え、平行平 板の駆動方向に参照振動を励振する。上部の構造の振動 方向は参照振動の振動方向に対して直交しているため、 参照振動方向には剛性が高く、ほとんど変形がおこらな い。外部から回転が加わると、振動方向に対して直交す る方向（検出方向）にコリオリ力が発生する。この力に より上部の側面に張り付けた圧電材料に集中歪みが起こ り、正圧電効果により電荷が発生する。この集中電荷を 計測し角速度を求める。

このように平行平板構造を用いることにより、平行平板 型ジャイロセンサは従来の振動型ジャイロセンサに比べ、

・駆動部による参照振動が検出部に影響を起しにくい 構造である。

・コリオリカによる変形を集中電荷に変化することが できる。

- 共振周波数の調整、漏れ振動の抑制が可能である。 の特長在持っている(7) (8)。

\section{3. 平行平板型ジャイロの改良}

平行平板型ジャイロセンサの作製工程は図 2 ね示すよ うに機械切削による母材の切り出し(図 2-a)、及び平板構

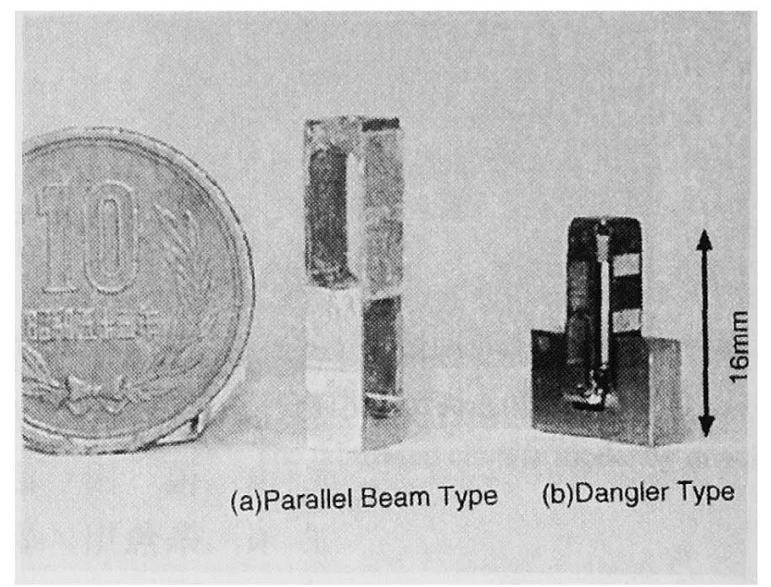

図 1 平行平板型ジャイロセンサと吊り下げ型 ジャイロセンサ

Fig. 1. Parallel Beam Gyroscope and Dangler ype Gyroscope

造の作製 (図 2-b)、4 枚の圧電材の張り合わせ (図 2-c) の 3 つの行程がある。しかし切削加工で平板を作製してい るため平板部の厚みの均一性や、压電材料を 4 枚張り合 わせたときの位置の対称性を保つのは困難であり、作製 時に誤差が生じる。この誤差により、参照振動が検出方 向に漏れるメカニカルカップリングの影響が大きくなり $\mathrm{S} / \mathrm{N}$ 比が低下する。また生産性の䤄でも切削加工、及び 4 枚の圧電材の張り合わせ工程は量産には向いていない。

そのため我々はこの問題に対して板のプレス加工によ る平行平板構造の成形（図 3 - $\mathrm{a}$ )、及び水熱合成法に よる圧電材料の一括製膜 (図 3-b) を行い、固定部を取り 付ける (図 3-c) ことにより、作製時の誤差の影響を軽減 し、量産性を向上させ、また上部の構造を下部の中に折 り込むことにより構造の小型化及ずモーメントの影響を 軽減した図 1(b)のような吊り下げ型ジャイロセンサを試 作した。

まず、板厚 $300 \mu m$ のチタン板を幅 $3 \mathrm{~mm}$ 、高さ $11.5 \mathrm{~mm}$ の大きさになるようにプレス加.エで図 3-bのように加工 し、表面に水熱合成法により $\mathrm{PZT}$ 薄膜を均一に $15 \mu \mathrm{m}$ 成 長させる。その後、電極としてアルミを駆動部及び検出 部に蒸着し、アクチュエータメャンサに用いている。この 洔、駆動部の電極は振動変位を大きくするため平板部の 長さ全体に、検出部は歪みの集中する平板と支持部の境 界部のみに電極としてアルミを成膜している。そして固 定部を取り付け、平行平板構造を作製している（図 3-c）。

〈3・1〉 水熱合成法 東工大の大場らにより、水熱合 成法を用いて $\mathrm{Ti}$ 基板上に $\mathrm{PZT}$ 多結晶膜を直接形成でき ることが1991 年に報告されている(12)(13)。水熱合成で PZT 多結晶薄膜を作製する利点として、(1) 水溶液中で の成膜のため 3 次元構造物にも膜を作製することができ (2) 成長プロセスを繰り返すことにより厚い膜を作製す ることができ、(3) 分極処理が不要（自然分極）である。 


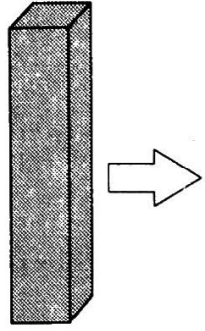

(a)因材の切り出し

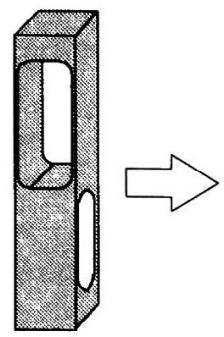

(b)切削加工によよる構造の作製

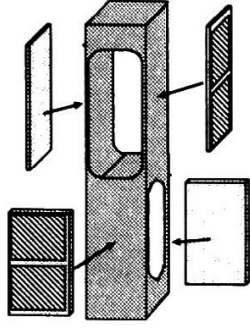

(c)/热朴料の张り付け
図 2 平行平板型ジャイロセンサの作製法

Fig. 2. Manufacturing Method of the Parallel Beam Gyroscope

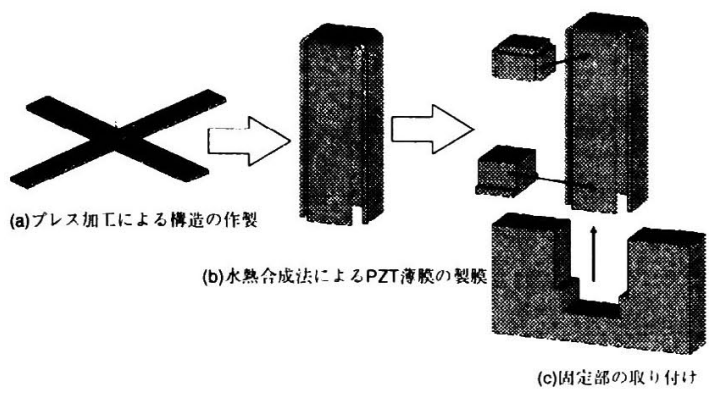

図 3 吊り下げ型ジャイロセンサの作製法

Fig. 3. Manufacturing Method of the Dangler Type Gyroscope

表 1 EDX による PZT 膜の組成分析結果

Table 1. fructification of the composition analysis of the piezoelectric creramics by EDX

\begin{tabular}{c|c}
\hline Constituent & PZT film was used for atm(\%) \\
\hline $\mathrm{Pb}$ & 55.91 \\
\hline $\mathrm{Zn}$ & 33.77 \\
\hline $\mathrm{Ti}$ & 10.31 \\
\hline Total & 100 \\
\hline
\end{tabular}

などが挙げられる。その後、東大の桶口らにより成膜条 件が改良され、マイクロ超音波モータや加振型接触七ン サ等について研究が行われている(14)(15)。

この方法は核生成プロセス (step1) と、結晶成長プロセ ス (step2)の 2 つに分けられる。核生成プロセスでは水 溶液中に $\mathrm{Pb}^{2+}, \mathrm{Zr}^{4+}$ イオンと、 $\mathrm{T} \mathrm{i}$ 基板との化学反応に より基板と結合力の強い $\mathrm{P} Z$ 多結晶膜を成膜させる。そ の後、結晶成長プロセスでは $\mathrm{Pb}^{2+}, \mathrm{Zr}^{4+}, \mathrm{Ti}^{4+}$ を水溶液 中に供給し、P Z T 多結晶を成長させる。

この様にして作製したPZT 多結晶薄膜の SEM 写真を 図 4 に示す。図 4 より 5 10 $\mu m$ の PZT 結晶が積層し成 長しているのがわかる。

今回作成した PZT 薄膜を EDX(堀場製作所 E-MAX 3700)を用いて組成比を測定した。測定結果を表 1 に示す。

表から分かるように今回作成した膜は $\mathrm{Pb}$ を 1 とする と $\mathrm{Zn}=0.6 、 \mathrm{Ti}=0.18$ となり、電気機械結合係数が最

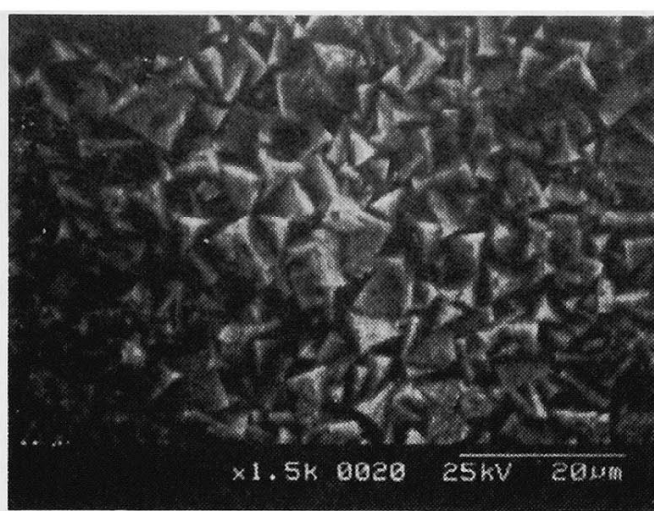

図 4 作製したPZT 薄膜の SEM 写真

Fig. 4. SEM Image of the PZT Thin Film

大となる組成比の $\mathrm{PZT}\left(\mathrm{PbZr}_{052} \mathrm{Ti}_{0.46} \mathrm{O}_{3}\right)$ と比べ、 $\mathrm{Ti}$ の 割合が低くなっている。

次に PZT 薄膜の圧電定数を計測するため、成膜時に脣 さ $30 \mathrm{~mm}$ 、幅 $5 \mathrm{~mm}$ 、厚み $50 \mu \mathrm{m}$ の評価用の $\mathrm{Ti}$ 板を混入 し、バイモルフ構造を作成した。DC電圧をバイモルフに 加え、その変位をレーザー変位計 (キーエンス:LC-2400) を用いて測定した。人力電圧をバイモルフの先端変位と の関係は

$$
\delta=\frac{3 l^{2}}{2 t} \frac{\left(1-a^{2}\right) Y_{f}}{a^{3} Y_{s}+\left(1-a^{3}\right) Y_{f}} \cdot d_{31} E,\left(a=\frac{t_{s}}{t}\right) \cdots
$$

$\left(l:\right.$ バイモルフの長さ、 $t$ :全厚さ、 $t_{s}:$ チタン板厚さ、 $Y_{f}: \mathrm{PZT}$ のヤング率、 $Y_{s}:$ チタン板のサング率) で示される(13) (14)。 ただしPZTのヤング率 $Y_{f}$ は

$$
Y_{f}=\frac{\frac{f_{s_{1}^{2}}^{2}}{f_{i}^{2}}\left(1+2 \frac{t_{f} d_{f}}{t_{*} d_{f}}\right)-1}{\varepsilon\left(\frac{t_{f}}{t_{*}}\right)^{3}+12\left(\frac{t_{f}}{t_{*}}\right)^{2}+6\left(\frac{t_{f}}{t_{*}}\right)} Y_{s}
$$

$\left(f_{c}\right.$ :バイモルフ構造の共振周波数、 $f_{0}:$ チタン板のみの共 振周波数、 $t_{f}: \mathrm{PZ}$ 膜の厚み、 $d_{f}: \mathrm{PZT}$ 膜の密度、 $d_{s}:$ チ タン板の密度) で示される。それぞれ $f_{c}=131.32 \mathrm{~Hz}$ 、 $f_{0}=103.0 \mathrm{~Hz} 、 t_{f}=15 \mu \mathrm{m} 、 d_{f}=4.27 \times 10^{6} \mathrm{~g} / \mathrm{m}^{3} 、$ $d_{s}=4.0 \times 10^{6} \mathrm{~g} / \mathrm{m}^{3}$ を実験より求めた。PZT のヤング率 $Y_{f}$ は $Y_{f}=5.373 \times 10^{10} \mathrm{~N} / \mathrm{m}^{2}$ となり、(1) 式より压電定 数 $d_{31}$ は $d_{31}=50.9 \times 10^{-12} \mathrm{~m} / \mathrm{V}$ であった。この值は焼 結による圧電セラミックスに比べ低い値になっているが、 EDX の評価より分かるように今回作成した PZT 薄膜の 組成比のコントロールが分で無かったことが原因であ ると考えられる。また図 4 に示したPZTの SEM 写真よ り分かるように表面が荒らいために、厚みが正確に測定 できないこと、作製した膜を PZT 膜単一の膜と仮定し、 (2) 式を用いて求めたことによる計算誤差も大きいと思 われる。

〈3・2〉 センサ部とアクチュエータ部振動型ジャイ ロセンサの感度を向上するためには一般的に検出側と駆 
動側の共振周波を近づけることが望ましい(16)。従来の平 行平板型ジャイロセンサ (図 5-a) の上部 (検出部) $f_{\text {upper }}$ の其振周波数は式（3）

$$
f_{\text {upper }}=\frac{1}{2 \pi} \sqrt{\frac{2 E b t_{u}^{3}}{m_{t} L_{\text {sensor }}^{3}}}
$$

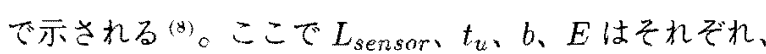
上部の平板の長さ、厚み、幅、材料の縌弾性係数で、 $m_{t}$ は上部先端の凰体の重さである。

同じように下部 (駆動部) について考えると、上部と 下部の駆動力向とは直交しているため下部の駆動方向の 振動に対しては剛体と考えることができる。上部全体の 重さを $m_{d}$ 、駆動部の平板の長さ、厚み、幅を、それぞれ $L_{\text {drive }} t_{l} 、 a$ とすると、下部の共振周波数 flower は以下 のようになる。

$$
f_{\text {lower }}=\frac{1}{2 \pi} \sqrt{\frac{2 E a t_{l}^{3}}{m_{d} L_{d r i v e}^{3}}}
$$

この 2 式が等しくなるように設計することが望ましい。 吊り下げ型棈造 (図 5-b) においても、平行平板構造の 特徴は保たれるため、上 2 式はそれぞれ吊り下げ部と 上部、構造支持部と下部とが対応する $\left(L_{\text {drive }}=L_{\text {fix }}\right.$ 、 $\left.L_{\text {sensor }}=L_{\text {hang }}\right)$ 。プレス加工で作製を行うため、こ0 二式の平板部の厚みを一定 $\left(t_{u}=t_{l}\right)$ として、共振周波 数を等しい $\left(f_{\text {upper }}=f_{\text {lower }}\right)$ とすると

$$
L_{f i x}^{3}=\frac{m_{t}}{m_{d}} L_{h a n g}^{3}
$$

となる。ここで $m_{d}$ 岲り下げられた構造全体の重さ、 $m_{t}$ は吊り下げられた先端の重りであるため、 $L_{\text {hang }}>L_{f i x}$ ととなり、吊り下げ部の平板の方が支持部より長くなる。 一般に速度 Vで振動している質量 $\mathrm{M} の$ 物体に角速度 $\Omega$ が加わったとき発生するコリオリ力は

$$
F_{c}=2 M V \Omega
$$

で示されるため、平板部の長い吊り下げ部分を駆動部に 用いた力が圧電材料による振動速度 Vが大きくなり、発 生するコリオリ力が增大する。逆に検出部では平行平板 構造特有の変形が生し、力は集中歪みに変換さ㧈るため、 平板の長さの影響は受けない。そのため吊り下げ型ジャ イロセンサでは図 5-(b)に示すように、平板の長い吊り 下げ部の方を駆動部に、平板の短い支持部の方を検出部 に利用している。

〈3・3〉共振周波数の調整 作成したプロトタイプは 有限要素法を用いて共振周波数が合うように解析を行っ た結果、全体の大きさ在高さ $11.5 \mathrm{~mm}$ 、幅 $3 \mathrm{~mm}$ 、板厚 $300 \mu \mathrm{m}$ のチタン板、上部の重り $m_{t}=0.26 \mathrm{~g}$ 、駆動部の重 さ $m_{d}=0.69 \mathrm{~g}$ とすると $L_{f i x}=5.5 \mathrm{~mm}, L_{\text {hang }}=7.5 \mathrm{~mm}$ となった。

またこれを式 (3)、式 (4) に代入すると $L_{f i x}^{3}=166.38$ 、

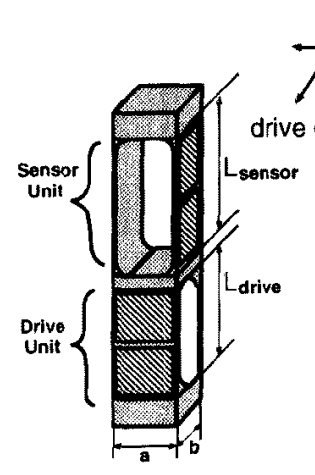

(a)Parallel Beam Gyrosocpe
$Y$

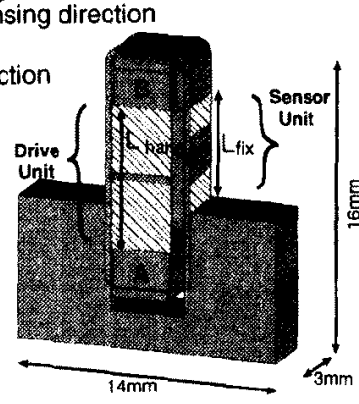

(b) Danglar Type Gyroscope
図 5 平行平板ジャイロセンサと吊り下げ型 ジャイロセンサの原理

Fig. 5. Priciple of the Parallel Beam Gyroscope and the Dangler Type Gyroscope

$\frac{m_{i}}{m_{d}} L_{\text {hang }}^{3}=158.97$ となり式（5）をほぼ満たしている。 この条件でプロトタイプを作製し、共振周波数を測定す ると駆動部 $1.774 \mathrm{kHz}$ 、検出部 $1.935 \mathrm{kHz}$ となり、2つの 共振周波数は離れてしまった。これは作製時の䛊差によ

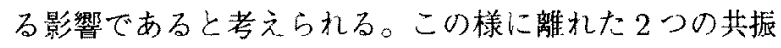
周波数を合わせるため、上部に重りを付加し共振周波数 をコントロールする方法を用いた(8)。これまでの平行平 板型とは異なり、駆動部は上部から吊り下げていること からら上部に重りを付加しても平行平板構造の重りの大き さは変わらないので共振周波数は変化せず、検出部のみ の共振周波数が変化する。今回上部に $0.091 \mathrm{~g}$ の重りを付 加することにより、共振周波数は駆動部 $1.767 \mathrm{kHz}$ 、検出 部 $1.788 \mathrm{kHz}$ となっだ。

〈3.4〉变形モードに関する考察平䘕平板構造の上 部に荷重が加わる上図6-(a)に示すような平行承板構造 特有の変形モードが現れ、歪みは平板と平板を固定して いる部分との境界に集中守る。このことを利用して平行 平板型ジャイロセンサでは平板の側面の電極を 2 分割し、 歪みの集中する場所からの出力のみを検出している。寒 際の平行平板構造では支持部が完全な剛体でないため、 図6-(b)に示されるように一様な曲げモードによる変形 も生じている。そのためコリオリカが上部に加わったと きに生じる変形はこの2つの変形モードの重悋合わせた 変形が生じる。従来の平行平板効型ジャイロセン+は平 行平板構造を2つ積層した構造になって扔り、下部の固 定端から上部の重りまでの距離が離れているだ、曲り゙ モーメントの影響が大きくなる上考えられる。そのため 検出部の 4 つの電極から発生ず電荷にはばらつきが生 じてしまう。図5-(b)のように上部の平行化板構造を内 部に入れる吊り下げた構造にすることにより曲げモ一・メ ントの影響が軽減され、平行平板構造特有の変形モード が大きく現れる。

図 7、怄 8 に吊り下げ型ジヤイロセンサの駆動部を駆 


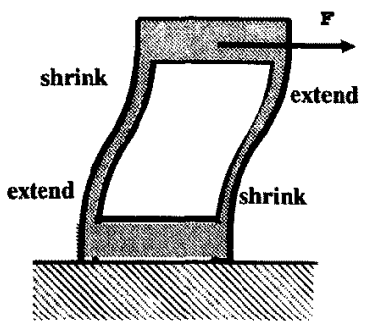

(a)Parallel Beam mode

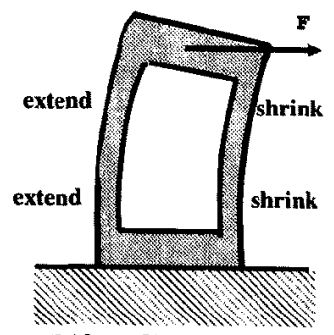

(b)bending mode
図 6 平行平板変形モードと曲げモード

Fig. 6. Deformation of the Paraliel Beam Mode and Bending Mode

動したときの沶動変位を示す。駆動部の 4 つの電極に位 相の 180 度異なる $5 \mathrm{~V}$ の正弦波を入力し、駆動方向に参 照振動を励振する。

その時の吊り下げ型ジャイロの駆動部端点（図 5 の A 点）および駆動部固定点（図 5 のB点）の駆動方向（X 方向:図 7) と検出力向（Y方向:図 8）の振動変位をレー ザードップラー振動計（グラフテック:AT3500）を用いて 測定した。図 7 より駆動部端点 (図 5-(b)のA 点)が駆動 方向に振動しているのに対して、駆動部固定点 (罗 5-(b) の $\mathrm{B}$ 点) は支持部の平行平板の駆動方向と直交している ためX方向には変形がおこっていない。

また図 8 より方向の変形は駆動部端点、駆動部固定 点の変形量がほほ同じであることから、駆動部は平行に 検出方向に駆動しており、曲げモードによる変形がほと んど生していないことが分かる。

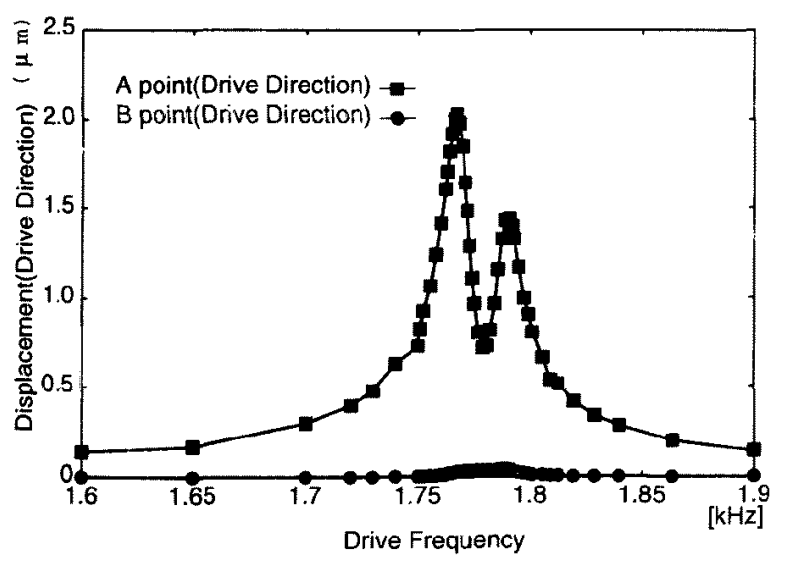

図 7 吊り下げ型ジャイロの駆動周波数と駆動 方向への振動変位との関係

Fig. 7. Relationship between the Drive Frequency and the Displacement to the Drive Direction

\section{4. 角速度検出}

作成したプロトタイプを用いて角速度の測定を行った。 角速度の測定原理は平行平板型ジャイロセンサと同じ

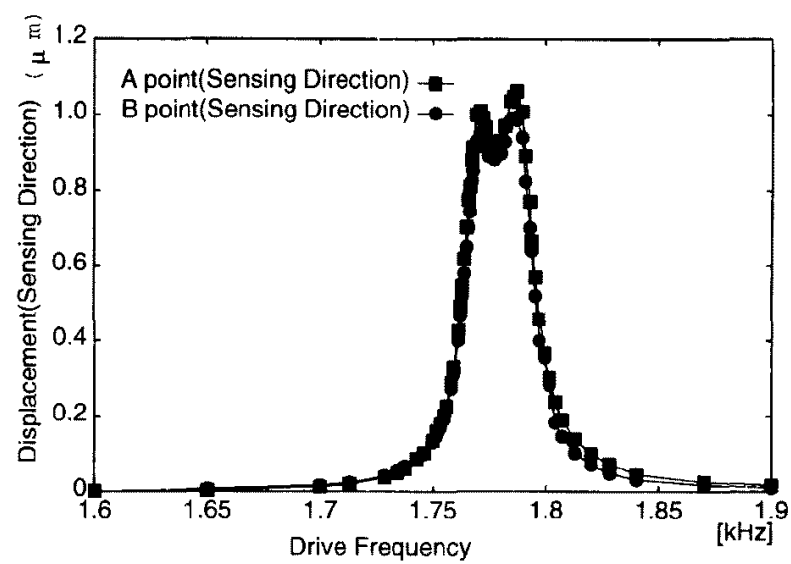

図 8 吊り下げ型ジャイロの駆動周波数と検出 力向への振動変位との関係

Fig. 8. Relationship between the Drive Frequency and the Displacement to the Sensing Direction

で、駆動部を用いて参照振動を励拨する。外部から回転 が加わると、参照振動に対して直交する方向（検出方向） にコリオリカが発生する。この力により検出部の側面に 張り付けた圧電朴料に集中歪みが起こり、正圧電效果に より電荷が発生する。この集中電荷を計測し角速度を求 める。しかし駆動部と検出部の共振周波数を近づけてい るため、駆動方向の参照振動が検出方向に漏れるメカ二 カルカップリングの影響が大きく現れ、検出信号に大き なオフセットが発生する。このオフセット電压により角 速度の検出が困難になる。振動型ジャイロセンサ索高感 度化するためには、このメカニカルカップリングによる 影響走少なくする必要がある。

$\langle 4 \cdot 1\rangle$ 漏九振動の抑制图 8 に示す様にメカ二カ ルカップリングによる影響により共振周波数近辺では検 出方向へ参照振動が大きく漏れているのが分かる。図 10 に駆動部の共振周波数 $1.767 \mathrm{kHz}$ で駆動した場合のA点、 及びB点での駆動軌跡を示す。駆動部に位相が 180 度異 なる $5 \mathrm{~V}$ の正茲波を上下の電極に加え、平行平板の駆 動方向に参照振動を励振し、X 万向、及びY 方向から計 測した結果を示している。図10から解るように非常に大 きな漏れ振動 (50\%の漏れ) が発生している。これは2つ の共振周波数が $20 \mathrm{~Hz}$ 程度しか離れていないことと、吊 り下げた構造をアクチュエータに用いたため往来と比べ 漏れ振動が発生しやすくなっているのが原因であると考 えられる。またこの漏れ振動により、㭘出部の下部電極

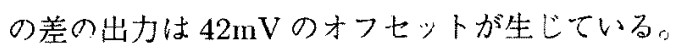

この漏れ振動を前回我々が提案した検出部の一部をア クチュエータに用いる手法(8)を用いて漏れ振動を㧕制し た結果を図 10 に示す。この手法は平行平板構造に荷重が 加わったときに 4 個所に生じる変形が捙成しているのを 利用している。図 9 のような回路を用い、駆動電圧に対 
して 150 度位相のずれた $\pm 11 \mathrm{~V}$ の正弦波を検出部の上部 に加えることにより、検出方向に発生する漏れ振動を $5 \%$ 程度に抑制している。この時、発生するオフセット電圧 を $10 \mathrm{mV}$ まで減少导せた。

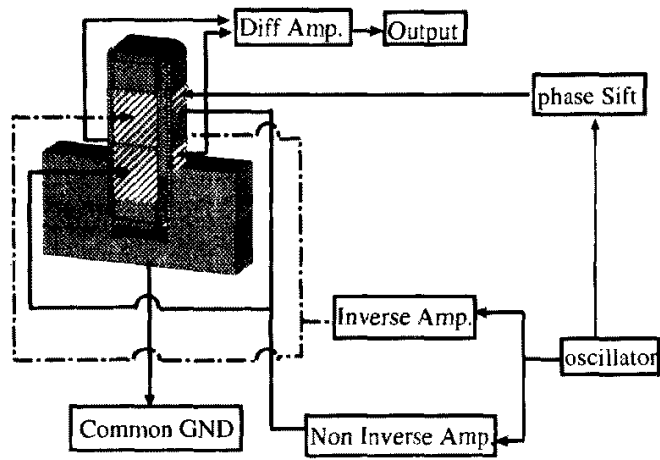

図 9 吊り下げ型ジャイロの回路

Fig. 9. Control Circuit of the Dangler Type Gyroscope

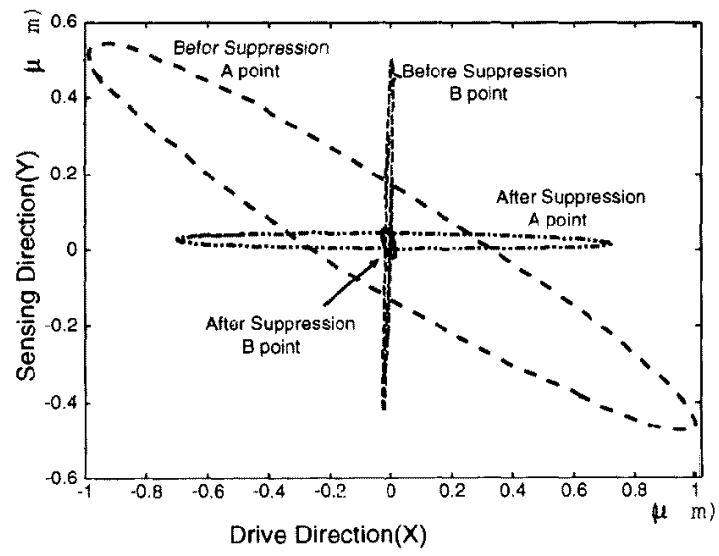

图 10 A 点と B 点の軌跡

Fig. 10. Tragectory of the A point and the B point

〈4・2〉角速度の測定 このようにメカニカルカップ リングの影響を抑制した状態で回転を加え、角速度省検 出した。四11に吊り下げ型ジャイロの角速度に対する出 力電压の特性を示す。図 9 に示す回路を用いて検出部の 2つの下部電極の差を同期検波を行わずに80倍に增幅し 振幅変化を読み取っている。

図 11 より角速度に対して出力電圧が比例していること がかかる。感度は従来の平行平板構造に比べ低下してい るが、これは水熱合成法により作成した压電薄膜が従来 のバルク材に比べ压電効果が低いのが原因であると考之 られる。

\section{5. まとめ}

本稿では、平行平板型ジャイロセンサの問題点である 構造の複雑さを解决するために、プレス加工、および水

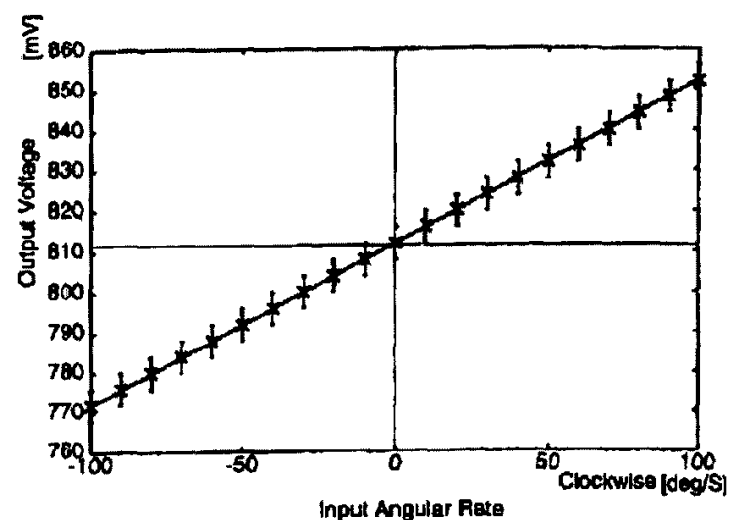

図 11 角速度を加えたときの出力

Fig. 11. Relationship between Output and Rotation Speed

熱合成法を用いて、切削加エによる加工誤差や圧電材の 張り合わせ位置のずれの影響を軽減し量産性に谪した吊 り下げ型ジャイロセンサを考案し、試作、評価を行った。 このように高感度ジャイロセンサがより低洒格で作製 することができるようになれば、これまでのビデオカメ ラの手振れ防止や車の姿勢制御などだけでなく、三次元 マウスなどの位置認識デバイス、ラジコン模型やゲーム 機器等のホビー用途への応用が期待される。

今後は水熱合成より作成した厈電薄膜の问上や、検出 部の電極にフィードバック制御した電圧を加えることに よる振動の抑制、AGC (Auto gain control) 回路による 参照振動の安定化を行い、さらなる感度向上、計測レン 沙の应大、出力の安定性を目指す。

(平成 12 年 9 月 25 日受付，同 12 年 12 月 13 日再受 付)

\section{文献}

(1) Jan Söderkvist" Micromachined gyroscopes" Sensors and Actuators A, 43 pp.65-71 (1994)

(2) Watson Ind.,ANGULAR RATE SENSOR APPARATUS, US Patent No. 4,628,734

（3）市瀬、寺田“音叉型振動ジャイロ”、日本工業出版、 超音波テクノ、Vol.6,Vol.9,pp.42-47

(4) W.D.Gates, "Vibrating angular rate sensor may threaten the gyroscope" Electronics, 41 (10) pp.130-134 (1968)

(5) S. Fujishima, T. Nakamura and K. Fujimoto, "Piezoelectric vibratory gyroscope using flexural vibration of a triangular bar" Proc. 45th Symp. Frequency Control, Los Angeles, CA, USA, pp $.261-264,(1991)$ 
(6) T. Fukuda, H. Sato, F. Arai, H. Iwata, K. Itoigawa "Parallel Beam Micro sensor/Actuator Unit Using PZT Thin Films and Its Application Example" International Conference on Robotics and Automation '98 Proceedings, pp.1498-1503 (1998)

(7) H. Sato, T. Fukuda, F. Arai, H. Iwata, K. Itoigawa "Analysis of Parallel Beam Gyrosocpe" International Conference on Robotics and Automation '99 Proceedings, pp.1632-1637 (1999)

（8）佐藤宏司、新井史人、福田敏男、系魚川貢一、塚原靖 典 “平行平板型ジャイロセンサの設計と解析” 電気 学会論文誌 E, Vol.120-E, pp.128-133,No.3 (2000)

（9）谷泰弘、畑村洋太郎、長尾高明、竹中規雄 “平行 平板形研削動力計に関する一考察（第 1 報）", 精 密機械、48, 6 pp.772-777(1982)

（10）畑村洋太郎、飯野謙次、小野耕三、高田龍二 “口 ボット用六軸力計の試み”機論 C54. 497 pp.241246(1993)

（11）畑村洋太郎、高田龍二 “ピン型ロードセルの開発” 機論 C54. 497 pp.241-246 (1993)

(12) K. Shimomura, T. tsurumi,Y. Ohba, and M. Daimon "Preparation of Lead Zirconate Titanate Thin Film by Hydrothermal Method" jpn.J.Appl.phys.30 pp.2174-2177 (1991)

(13) Y. Ohba, M. Miyauchi, T. tsurumi, and M. Daimon "Analysis of Bending Displacement of Lead Zirconate Titanate Thin Film Synthesized by Hydrothermal Method" jpn.J.Appl.phys.32 pp.40954098 (1993)

（14）森田剛、神田岳文、黒沢実、桶口俊朗、“水熱 合成法による PZT 薄膜の応用” 信学技報 US9730,pp.33-38,(1997)

(15) M.K.Kurosawa,H.Yasui,T.Kanda and T.Higuchi: 'Perforamance of Hydrothermal PZT Film on High Intensity Operation',Proc.of.the IEEE International Workshop on Micro Elctro Mechanical Systems(MEMS),pp56-61,(2000)

（16）前中一介、藤田 孝之、前田 宗雄 “振動型マイクロ ジャイロの設計指針” 平成 9 電学研資 33-42 電気学 会論文誌 E,Vol.118-E, pp.377-383, No.7/8,(1998)

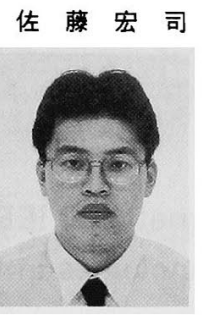

(学生員) 1995 年名古屋工業大学工学部電気情報 工学科卒業 1998 年名古屋大学大学院工学研究科 マイクロシステム工学専攻修士課程修了同年同博 士後期課程に進学し、現在に至る。センサ、アク チュエータに関する研究に従事, 現在に至る。
新井史人

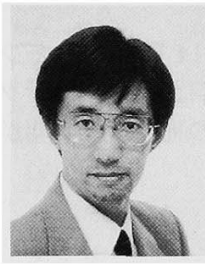

(正員) 1988 年東京理科大学大学院修了、88 年富士写真フィルム入社、 89 名古屋大学助手、93 年工学博士 (名古屋大学)、94 年名古屋大学大学院 工学研究科マイタロシステム工学専攻 諈師、98 年より助教授、現在に至る。マイクロシステム、マ イクロロボティクス、インテリジェントシステム 等の研究に従事。電気学会、I E E E などの会員。

福 田敏 男 (正員) 1977 年東京大学大学院博士課程修了、

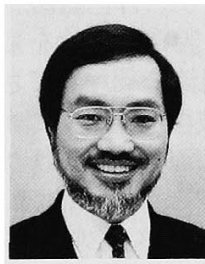
77 年通産省工業技術院機械技術研究所、 82 年よ り東京理科大学工学部講師、83 年助教授、 89 年 4 月、名古屋大学工学部教授、 94 年名古屋大学大 学院工学研究科マイクロシステム工学専攻教授、 97 年より名古屋大学先端技術共同研究センター教 授、現在に至る。知能ロボット、自己組織化ロボッ ト、マイクロシステム、メカトロニクス、計算機 知能、等の研究に従事。電気学会、I E E E な゙゙の会員。現在 I E E E Robotics \& Automation Society 会長。

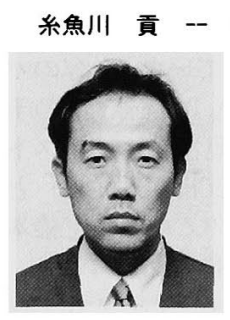

(正員) 1982 年日本大学理工学部電子工学科卒業。 同年, 株式会社東海理化電機製作所入社，半導体 プロセス,マイクロマシンに関する研究，開発に 従事, 現在に至る。

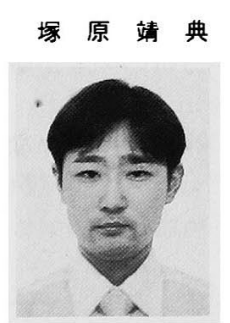

（非会員） 1998 年名古屋大学大学院量子工:学専攻 前期博士課程修了。同年, 株式会社東海理化電機 製作所入社，センサに関する研究，開発に従事，現 在に至る。 